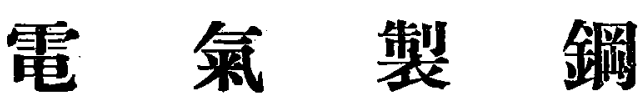

\section{第五卷 第三號}

昭和二年三月十五日

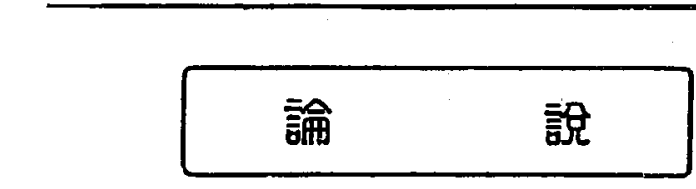

常輝鋼に就て（其一）

會員 理學博士 H. E. 生

I. 常糊铜

3. 常冣銅の常温加工

5. 常輝銅の棬械的性質乏物理的性筫

7. 常辉銅に业す万酸の作用

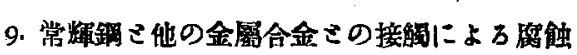

2. 常数銅 の棒法

4. 常辉鋼の機械仕上げ

6. 空氣中及び海水中に於け万常粼銅の腐蝕抵抗性

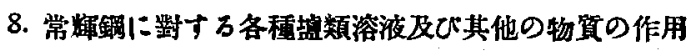

\section{I. 常 輝 鋼}

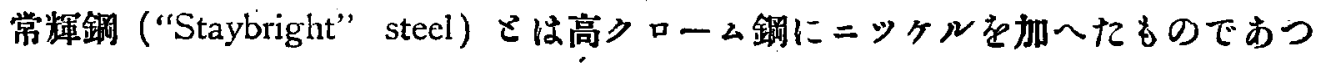

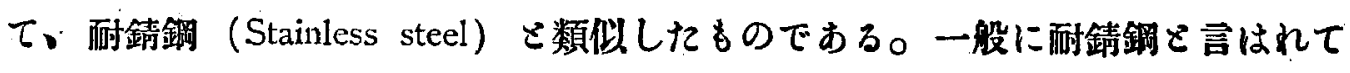

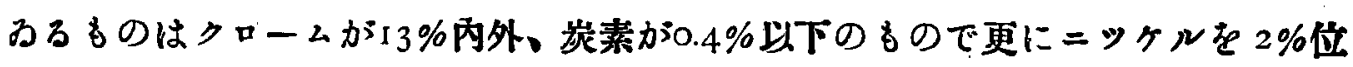
スれたもの、或は珪素をI\%位入れたものを總稱してわる。實質から言へばこの耐

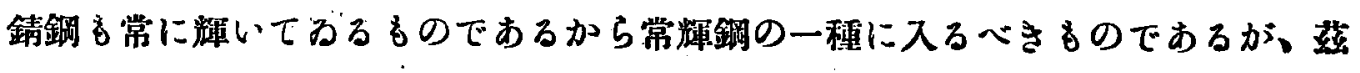

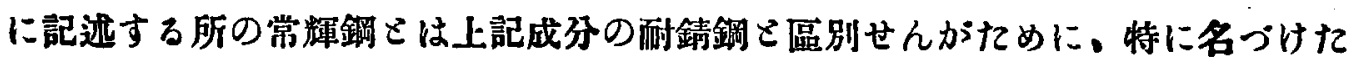
るので炭素は極めて少量でクロームI5〜20\%、ニッケル8〜IO\%位のるので常温 に於ては太洲田組織のるのを言ふのである。特に Staybright の名稱は Sheffield の Messrs. Thos. Firth \& Sons. Ltd の製品に名づけられたもので、獨逸 Messrs. Fried. Krupp の V. 2. A 及び Messrs. Brown; Beyleys' Steel. Works. Ltd Ф 
“Anka”と同樣にクロームニッケル鋼の一つである、即ち左表の如し。

\begin{tabular}{|c|c|c|}
\hline 名 & $\% \mathrm{C}$ & $\% \mathrm{Ni}$ \\
\hline “Staylbright" & $\mathrm{r} 8$ & 8 \\
limpp V. 2. A." & 20.4 & 8.6 \\
Anka" & 15.2 & 11.4 \\
\hline
\end{tabular}

茲に浪許に Messrs. Thos. Firth \& Sons. Ltd 上り著者の元に䢪り稀つた Staybright 鋼に ついての郝告を紹介するものである。

この常辉銅の特性は十分軟化した狀態にす

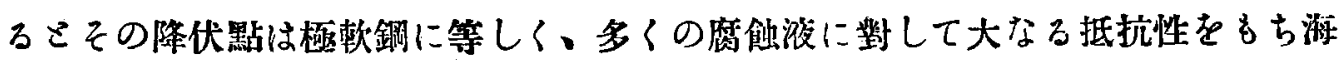

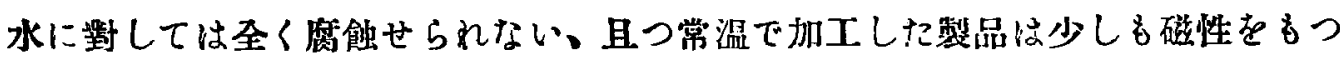
てるない、鋼を呼ばれてるなから却つて非鐵合金に類似する特性をるつつてるる。 泩文に應じて最大の柔㳄性をもたしたら、大なる腐飿抵抗性さ同時に抗張力をる たす事を得るので同會社では bars, Sheets, forgings, tubes 及び Wire の形で賣り 出し、鑄物となした時には之を “Noncrode”を呼んで販賣してるる。

棒山軟化の狀態或は抗張力の大なるものとして 3/16" から 4" の丸又は角棒が あり、鍛鍊したものは 4" 以上の大きさに各種の形のものがある。

板は薄板こして十分に㳄化して scale をこつたもので $6^{\prime} \times 3^{\prime}$ の薄板まである。 大いなものこして次の各種なるのがある。

\begin{tabular}{|c|c|c|}
\hline 厚さ & 長 さ & 巾 \\
\hline $5 / 8 "$ & $20^{\prime}-\mathrm{O}^{\prime \prime}$ & $5^{\prime}$ - \\
\hline $9 / 16^{\prime \prime}$ & $20^{\prime}-0^{\prime \prime}$ & $5^{\prime}-0^{\prime \prime \prime}$ \\
\hline $1 / 2 "$ & $2 \mathrm{O}^{\prime} \longrightarrow \mathrm{O}^{\prime \prime}$ & $5^{\prime}-0^{\prime \prime \prime}$ \\
\hline $7 / 16^{\prime \prime}$ & $2 \alpha-0^{\prime \prime}$ & $5^{\prime}-0^{\prime \prime}$ \\
\hline $3 / 8 "$ & $15^{\prime}-\mathrm{o}^{\prime \prime}$ & $4^{\prime}-6^{\prime \prime}$ \\
\hline $5 / 16^{\prime \prime}$ & $15^{\prime}-\mathrm{o}^{\prime \prime \prime}$ & $4^{\prime}-6 \prime \prime$ \\
\hline $1 / 4 "$ & $15^{\prime}-0 \prime \prime$ & $4^{\prime}-0^{\prime \prime}$ \\
\hline $3 / 16^{\prime \prime}$ & $15^{\prime}-0^{\prime \prime}$ & $4^{\prime}$ - \\
\hline $1 / 811$ & Io'-O' & $3^{\prime}-0^{\prime \prime}$ \\
\hline
\end{tabular}

管は solid-drawntubiug する事加出桃 15 20吹 までの長さのむのまで出豖、直徑は色々のむのが ある。この solid drawnした管は十癹に軟化した ものも艾 cold drawn したものもある。又 Weld した管もある。

針金も各程のものが出來軟化し scale をとつた もの colddrawn :したものがある。

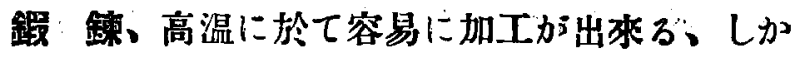
む形や大きさに制限なく出爽るこのここである加 ら、各種のものが鍛鍊のまつのもの、更に之れに芫仕上げをしたものっ製品があ 乃o 


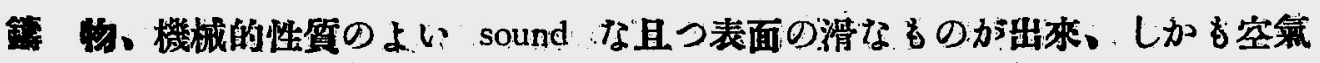
中、海水及ひ他の試藥に對して强いるのが出來る。同社では原形を受ければそれ によつてその鑰物を作ると言ふてわる。

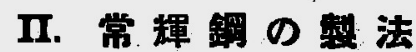

之は電妞㠊で彆造するものでクロームは熔融した錋中へ純粹なフェロクローム として添加する。ニツケルは純粹なるのる加へる。材料は極めて純粹なるのる使 用するので出來上り、帮品す從つて純粹であるから他の不純物が含有せられてる

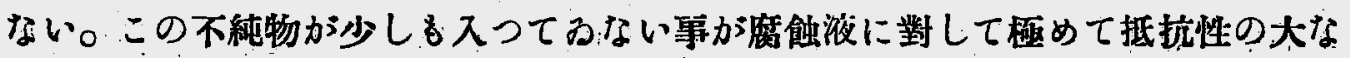

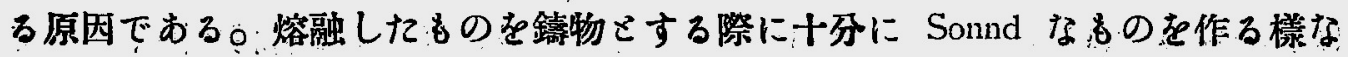
型る使用してるる。上部は廣く下部は㷋い型を用ひ鑄型の頭部には而水物を淮つ た feeder head やつけて收縮管を出棑るだけ小さくしてるる。 Ingots は柜めて大

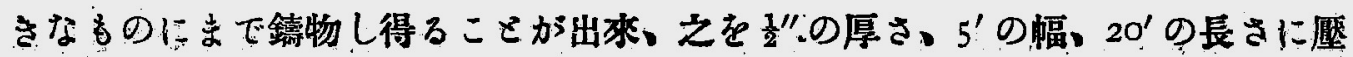

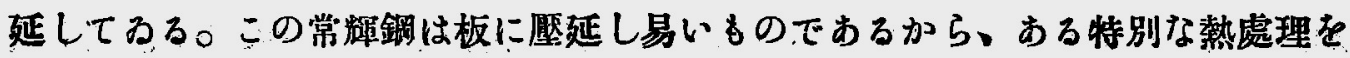

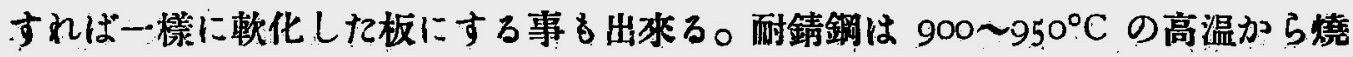
スするこ硬化する。一般には更に之を700Cに燒戻する。常輝鋼は之に反して高 温から燒入するこ軟化せられる事はマンガン鋼と同嵄で太洲田組織である。隨つ

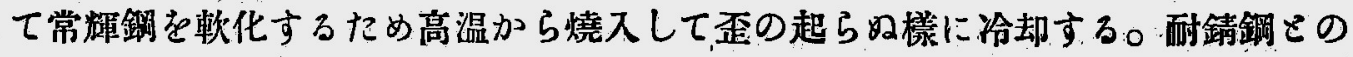

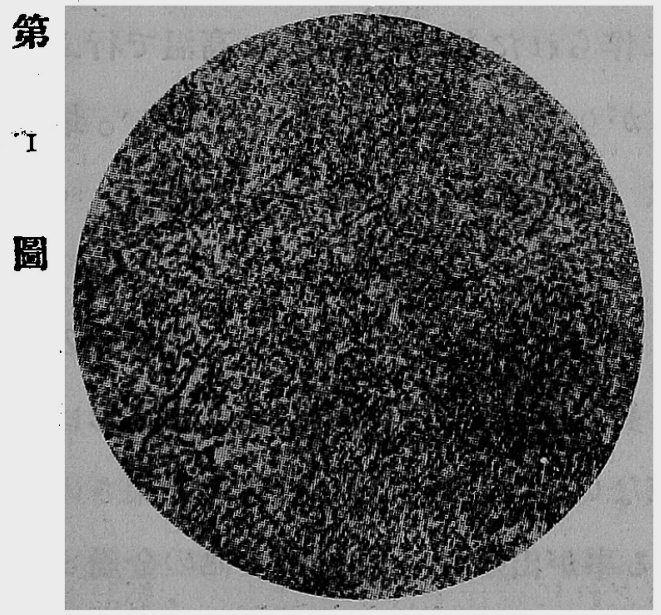

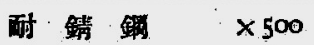

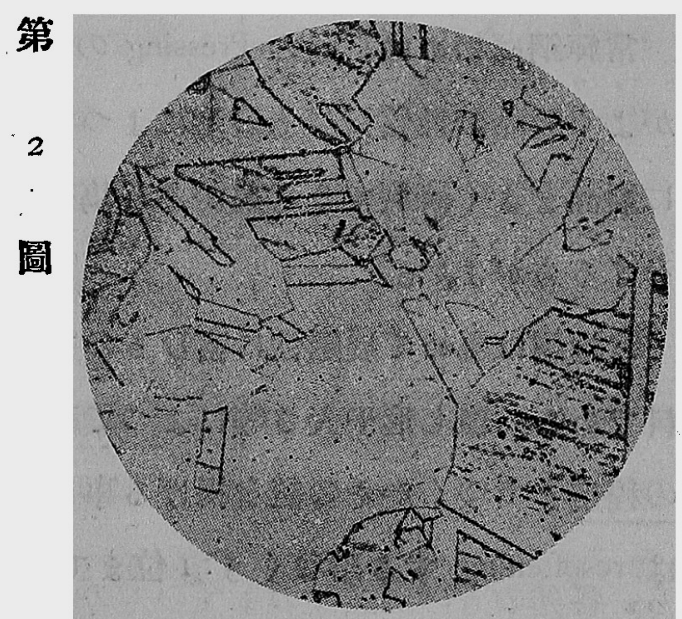

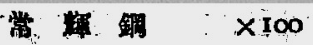




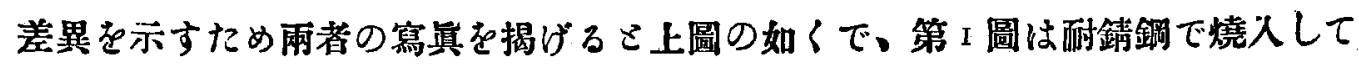

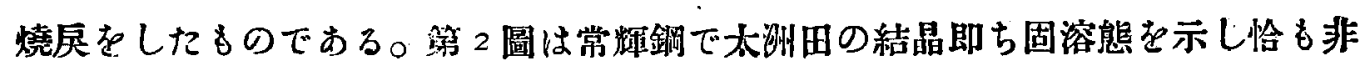
鐵合金で見る如き組織を現はしてるる。Messrs. Thos. Firth \& Sons 會社では常 輝鋼を製造する際に均一性こその他の特性を遺揻なく發揮せしめる橙に、色々を 經驗上の注意を排つてるるこ言ふ事である。

\section{III. 常輝鋼の高熱加工}

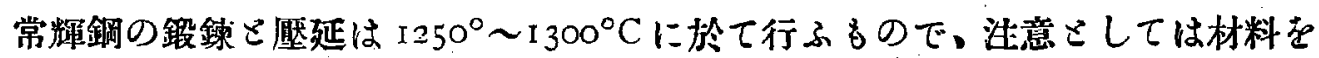
よくその温度に保つ栐にする。高温加工は出來る丈け早く行ひ大きな材料の時に は.950 $\mathrm{C}$ 以下になるまで續けてはならない。 $950^{\circ} \mathrm{C} に$ に近づくを材料は固くなつて

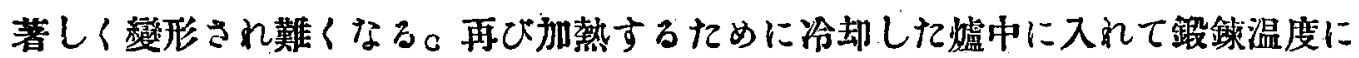
上杽し、材料が全部この温度になつた所で取っ出して始めには極く輕く鍜錚して 漸次に激しく手早く行ふ。常輝銅の高温加工の際に一つの特點とる見るべき事は 加熱の時の膨脹と冷却の時の收縮の大さか軟鋼の年分位である事である。最も軟 化し展延性に富んだ狀態で材料を使用するためには之を更に $\mathrm{I} 100$ I $1200^{\circ} \mathrm{C}$ 上昇 にして速かに椧却するこょい。しかし高温加エしたものでる機械仕上げする事が 出來る。

\section{Hot Pressing \& Cold Pressing.}

常輝鋼は初めは常温のPressing のてめに作られてものであるが、高温で行ふ方 がよく製品の性質及びその形によつて異るが 900〜12500 で行ふのがよい。最後 に製品をよく研磨する必要がある算合には hot pressing 老行つてるる間に seale をこる方がよい。

常輝鋼は極めて展延性に富むものであるから常温で press するには好都合の材 料である。但し形や大さ等によつて著しく異るから一回の press による變形は民゙ の程度までゆくかその值を揭げる事は出承ないが、概略を言へば直俓と深さの比 は resofteningする事なく $3:$ 工位までにする事が出來る。常輝龬も他の金屬と同 樣に常温加エによつて硬化する。故にもし著しく pressing や drawimg を行必要 
がある時には燒鈍をせね洼ならない。即ち $900 〜 1000^{\circ} \mathrm{C} に$ 加熱して空中冷却する゙ そ pressing に先つて十分に展性が得られる。軟化處理る行つた製品は :pressing の後に scale を取る事は勿諭である。

䗷鈍

常温加工の䨐めに軟化する必要があるこきには普通の方法で燒鈍すればよい。

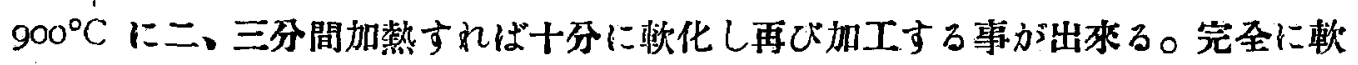

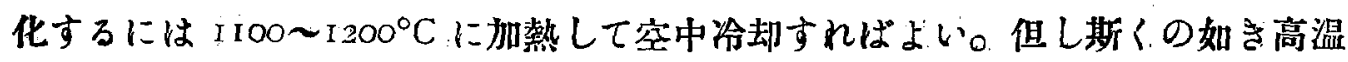
には出來るだけ短時間保持しなければならない。軟化後に scale をとる。

\section{Rivetting}

此の操作は別に困難ではなく常踔鍓は變形し易いるのであるから、小物は常温 で容易に rivet する事加出桃る。但し大物はI000〜 I $100^{\circ} \mathrm{C} に$ 於て行ふのがる L. Wo

\section{Soft-Soldering}

Soft-Soldering する事も容易である、但しその部分を粫め清淨にする必要があ ろ。出來うれば50\%の盐酸中に浸すのがよろしい。若し浸すここが出來なければ 盐酸で拭ふてからその部分をよく清浄な水で洗つて乾いた布で拭きとつて乾燥す

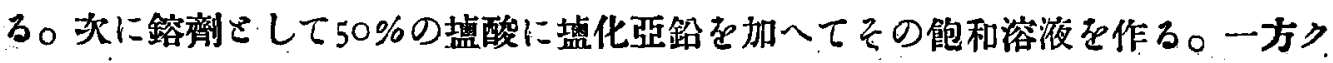
リーム狀となるまで50\%盍酸に笽化亞鉛を加へて薄い paste を作つて之を鑞附す へき部分に芼部蔽ふ位につける。tinning にしろ solderingにしろ普通の白鐦を使 用して普通の方法で行へばよい。操作後には盐酸の痕跡をも洗ひ去るために十永 に水洗ひする。

\section{Hard-Soldering \& Brazing}

（a） Blow-pipe (吹管法)で行ふ㙋合には鑘附する部分をよく清淨にする事上 記の塲合と同㧼で、50\%の墟酸で處理する事す同㧼である。鎔劑として矹砂る使 用し加熱の間にはその部分をよく矹砂をもつて蔽ふ事が必要でする。さむない時

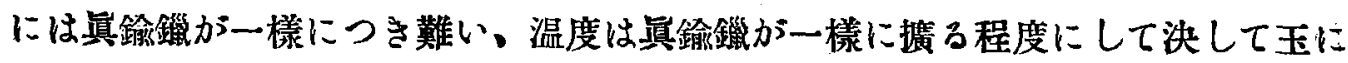


ならぬ樣にせなりればならない。常輝鋼について行ふ時は普通に行ふ温度よりる や〉高くするとよい結果が得られる樣である。

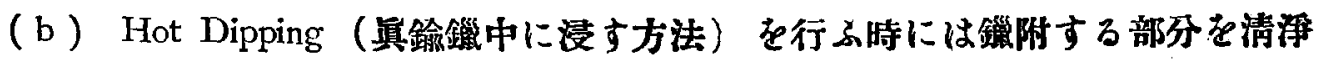
にする事は勿論であるが、最も必要な事はその部分を畺鍮の熔融温度近くまで像 熱する事である。斯くするけめに虫試料の表面に矹砂の居を流して dip すべき。

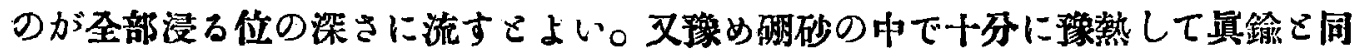
温度になつた所で熔融して其鍮の中に浸すのである。浸してから引き上げ冷却は 普通行はれてるる方法こ同樣にすればよい。高温の dipping の間に時こして浮渣

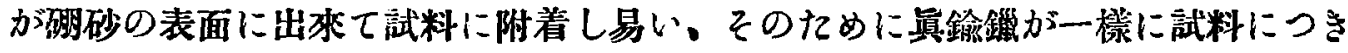
難くなる。この缺點を除くために陚料を dipping する前に上記の Soft-Soldering

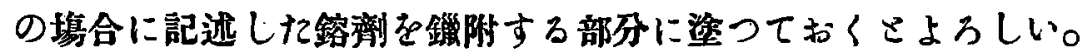

鎔接

(a) 常輝銅は smith' hearth ではうまく叙接する事が出來ない。

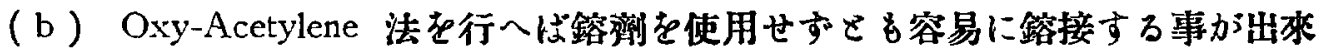
る。鎔接すべき部分を清淨にする事は勿論であるが同會社で scale を除去した状 㮩で販賣せられてるるものは、そのまつで鎔接し得られる。若し表面がよごれて わる場合には50\%の盐酸で拭ふてから水洗ひをする。及 scale がてつてなければ 鎔接すべき部分を研磨して sccle 苍るる。鎔接の際には无斯の出し方を加減して

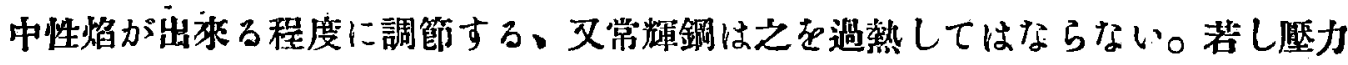
があまり大であるこ試料を貫通する、特に薄物にはその惢が多い。雨側から鎔接 する樦合には一方の側を豁接してから、次に他方の側を清淨にしてから豁接を始 める。

（c）笔抔鎔接法によつても亦容易に鎔接することが出來る。この時には值流

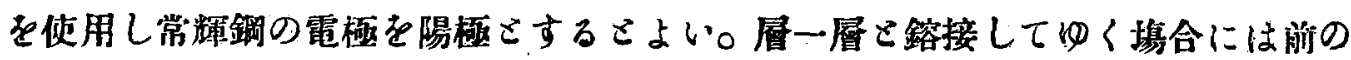

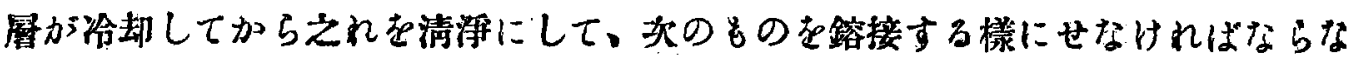
No 


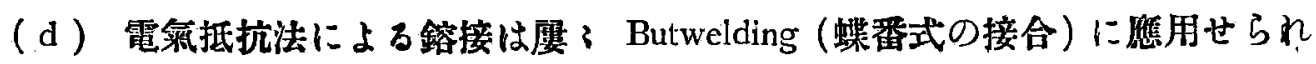

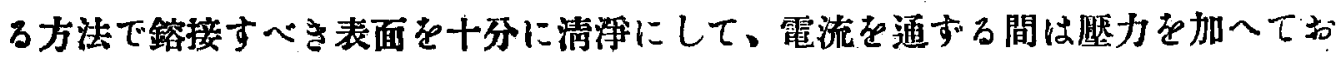
く。鎔接の速さ等の調節はその部分が全部同時に鎔接温度になる㧼にする事で、 相賞に經驗苍要する手際こ考へられる。

\section{Tinning}

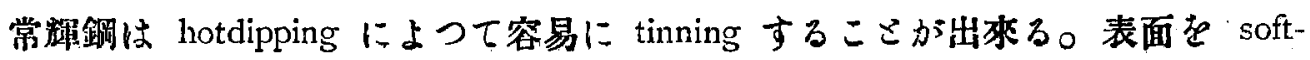
soldeing の所で記迅した如くに十分に゙清淨にする。即ち50\%の歶酸中に浸すか㕛 は之をるつて拭らてから十分に水洗をして布をるつて乾燥する。次に镕劑こして は50\%の盐酸に盖化亞鉛を溶解して飽和溶液をなしたるのを使用する。tinningす る部叧を之に浸すか塗布してから熔融して錫中に浸す。

\section{Pickling}

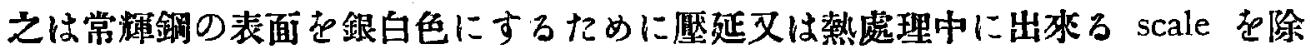
去するた的に行ふすのである。 scale をこつて表面を腐玲抵抗性の仕上りこなし、 且つ氛持ちよい外観を興へる。之がけあには適當な酸槽を使用すればよろしい。 最後に多量の水をもつて酸を洗ひ落す。

\section{Etching}

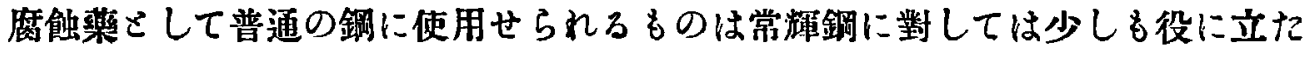

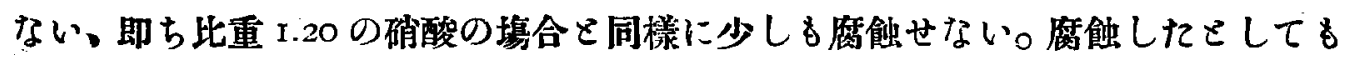
極めて緩慢のものである。隨つて常輝鋼に對しては適當な試藥を選ぶ事は甚だ困 難で、腐蝕藥こして單純な酸では常温に於て十分に勃能のあるすのは殆んごない 仍つて普通に常輝鋼の腐蝕蓃こして次の成分の混合酸を使用する。

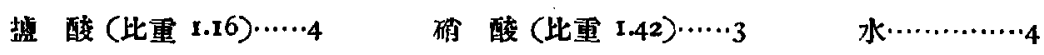

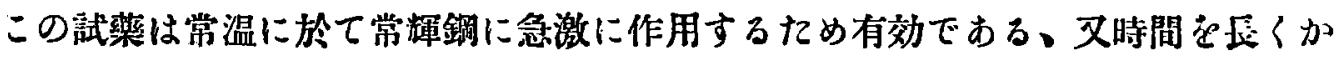

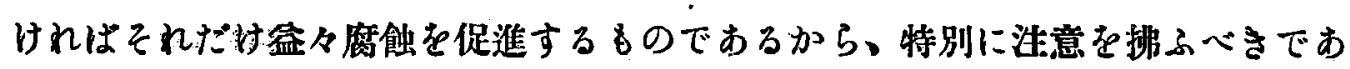
ろ

\section{常喗鎡の研哾}


常輝鎆の表面をよく研脂する事は甚しく困難な事ではない。適當な泩意を拂へば 鏡の如く輝いて表面を作る事が出爽る。各種程度の研磨紙と研磨粉を使用して念

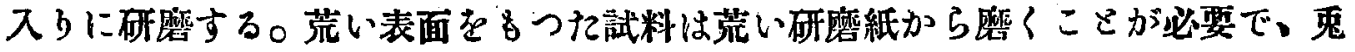
に角初めに荒い凹凸のある表面を十分に除去せねばならない、次にもつを細い研 筑紙走もつて上記の荒い研磨紙の傷痕を十分に除去する、斯の如き方法を順次に 操返して最後に酸化クロームの粉末さ最も細い研磨紙で鏡磨きを行ふ。又最後に Stearine 加ら出棑てるる物質をもつた塊即ち固體羊脂を使用する事もある。次に felt（䑕）の圓板を迴轉してその上に酸化クロームをかけて仕上げをするこ、表面 は光輝をるち鏡の如くこなる。(未完) 